\title{
A construção da imagem do escravo em ações de liberdade na comarca do Rio das Mortes no século XIX ${ }^{i}$
}

The construction of slave image in freedom lawsuits of the nineteenth-century in the district of Rio das Mortes

\author{
Carla Leila Oliveira Campos \\ Instituto de Ensino Superior Presidente \\ Tancredo de Almeida Neves/FUNADESP \\ Cristiano Lima da Silva \\ Instituto de Ensino Superior Presidente \\ Tancredo de Almeida Neves/FUNADESP \\ Roberto Rômulo Braga Tavaresi \\ Instituto de Ensino Superior Presidente \\ Tancredo de Almeida Neves/FU
}

\section{Resumo}

Este trabalho se insere no quadro teórico da Análise do Discurso e objetiva analisar o papel das unidades lexicais na construção da imagem do escravo em ações de liberdade e de manutenção de liberdade do século XIX na Comarca do Rio das Mortes. Analisamos dois processos: Anna Crioula (1838) e Ritta Guilhermina de Jesus (1863). Nessas análises, observamos o papel da formação discursiva escravocrata na construção da imagem do negro e as possibilidades de novos sentidos quando essa formação discursiva é posta em relação com seu exterior.

\section{Palavras-chave}

ações de liberdade; discurso jurídico; imagem do negro; léxico e história. 


\section{Abstract}

Within the theoretical framework of Discourse Analysis this article aims to investigate the role of lexical units in the construction of slave image in freedom lawsuits from the nineteenth-century in the district of Rio das Mortes. We analyzed two cases: Anna Crioula (1838) and Ritta Guilhermina de Jesus (1863). Throughout these analyses we observed the role that slavery discursive formation played in the construction of slave image, as well as the possibilities of producing new meanings when this discursive formation is placed in relation to its exterior.

\section{Keywords}

freedom lawsuits; legal discourse; slave image; lexicon and history. 


\section{Introdução}

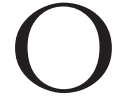

presente trabalho se insere no quadro teórico da Análise do Discurso (AD) e tem por objetivo investigar como se dá a construção da imagem dos escravos nas ações de liberdade de Anna Crioula, datada de 1838, e de manutenção de liberdade de Ritta Guilhermina de Jesus, datada de 1863, ocorridas na Comarca do Rio das Mortes, que tinha São João del-Reiiii como sede administrativa. Para tanto, o trabalho visa a investigar, por meio da análise de unidades lexicais presentes nesses textos, o modo como a imagem do escravo era construída nas tramas discursivas com vistas a justificar sua libertação, já que nem sempre havia uma lei que sustentasse o pedido.

Segundo Grinberg (1994), as ações de liberdade são processos jurídicos mediante os quais os escravos, representados por seus curadores, lutavam pelo direito de se tornarem livres. O estudo dessas ações ocorridas na Comarca do Rio das Mortes durante o século XIX fundamenta-se na análise desse instigante processo judicial que envolve, por um lado, escravos lutando pelo direito de se tornarem livres e, por outro, senhores buscando a manutenção do domínio sobre sua propriedade.

Por estar situado no quadro teórico da Análise do Discurso, o trabalho assume uma concepção de linguagem que compreende que todo sentido se inscreve em uma historicidade específica. Nesses termos, a AD está preocupada com a observação das condições sócio-históricas de produção desse sentido. Dentre os pontos que devem guiar as investigações do analista de discurso podemos destacar os seguintes: 1) a preocupação com o fato de o sujeito escolher, no seu relato, determinada organização dos acontecimentos e não outra; b) o questionamento do motivo pelo qual, na seleção dos eventos que iriam constituir suas práticas, o sujeito focalizou esses e não tantos outros possíveis; 3) a 
investigação de como a situação histórico-social em que o sujeito se inscreve o leva a representar o evento nessa configuração e não em outra.

Nesse sentido, faz-se importante destacar a afirmação de Maingueneau (2007, p. 16) de que as unidades do discurso se constituem em sistemas significantes, ou seja, enunciados que "têm a ver com a história que fornece a razão para as estruturas de sentido que elas manifestam".

Assim, para investigar como, nos processos em questão, era construída a imagem dos escravos, adotar-se-á uma metodologia interdisciplinar de abordagem do corpus, envolvendo os pressupostos teórico-metodológicos da AD e os estudos históricos sobre a escravidão e as relações sociais no século XIX. Tal estudo justifica-se pelo próprio caráter interdisciplinar da AD, já que um de seus pressupostos de base é o de que, para se compreenderem os efeitos de sentido expressos na superfície textual, faz-se necessário relacionar o texto a suas condições sócio-históricas de produção, com vistas a se compreender o efeito do histórico e das relações sociais na constituição do sentido.

Nesses termos, ao propor o estudo das unidades lexicais que contribuem para a construção de uma determinada imagem do negro no discurso jurídico do século XIX, o trabalho em tela compreende, conforme Pêcheux (1975), que as palavras não possuem um sentido que lhes seria próprio, pois seu sentido se constitui no interior das formações discursivas (FDs) em que emergem e na relação que tais palavras mantêm com outras palavras da mesma formação discursiva.

As formações discursivas, enquanto conjunto de regras anônimas que determinam aquilo que pode e deve ser dito em uma conjuntura social dada, marcam justamente a relação entre o histórico e o discursivo no interior da prática de linguagem. Nesse sentido, falar em construção da imagem do negro no discurso jurídico do século XIX envolve a compreensão do modo como as formações discursivas vigentes na época subjazem à prática discursiva.

Dessa forma, o trabalho subdivide-se em três momentos. Em um primeiro, apresentar-se-á o quadro teórico-metodológico de análise do corpus, abordando-se alguns conceitos fundamentais da AD e a metodologia de análise a ser utilizada. Em um segundo momento, será realizada uma breve contextua- 
lização histórica do período em que os processos ocorreram, bem como da tramitação legal desses processos. Finalmente, apresentar-se-á a análise do corpus mencionado, com base nos aspectos teóricos descritos.

\section{Quadro teórico-metodológico de abordagem do corpus}

Inserido no quadro teórico da Análise do Discurso (AD), o presente trabalho vincula-se a uma abordagem que tem por objetivo examinar as relações entre as práticas discursivas e o meio histórico-social no qual se originam. Desse modo, diferentemente das vertentes que tomam a linguagem seja como um reflexo transparente da realidade seja como uma representação objetiva do pensamento, a $\mathrm{AD}$ considera que toda prática linguística vem atravessada pelas relações sociais nas quais se situa, sendo, pois, o discurso um objeto fundamentalmente opaco.

Localizando-se em um quadro que reafirma essa postura teórica, os trabalhos em AD procuram compreender como os textos expressam e reproduzem as relações sociais e as visões de mundo dos sujeitos discursivos, considerando as condições de produção desses textos enquanto manifestações discursivas. Nesse sentido, as condições de produção referem-se ao conjunto de elementos que estão envolvidos na produção discursiva, como as relações que unem os sujeitos, os papéis sociais que desempenham e as condições históricas de emergência do dizer.

Segundo Possenti (2007), o texto não é uma unidade de análise, se não associarmos texto e contexto. A relevância do texto para a $\mathrm{AD}$ decorre do fato de que cada texto é parte de um arquivo, podendo ser tomado como uma superfície discursiva, como uma manifestação de um processo discursivo específico. Um texto faz sentido não somente por sua relação com o contexto, ou em decorrência de conhecimentos do leitor, mas também por resgatar uma ou mais formações discursivas, que, por sua vez, se inserem em uma memória discursiva, atravessada pelo interdiscurso ${ }^{\text {iv }}$. Todo texto significa, pois, em relação às suas condições de produção e ao interdiscurso.

Dentro dessa mesma perspectiva teórica, Brandão (1993) caracteriza o discurso como um sistema de estratégias das quais o locutor se utiliza para transmitir o enunciado. Permitindo ou excluindo certos temas ou teorias de seu discurso, o 
sujeito busca apagar as contradições e as formas de conhecimento que negam o seu dizer, dando a ideia de unicidade.

Para Maingueneau (2007), entretanto, essa unicidade é apenas aparente, já que as formações discursivas não podem ser tomadas como blocos fechados de controle dos sentidos, pois os limites das formações discursivas não estão claramente determinados, havendo uma primazia do interdiscurso em relação ao intra-discurso.

De acordo com o autor, ainda, os estudos da AD se relacionam com os textos produzidos em instituições que restringem a enunciação, entendendo os textos como o lugar em que se cristalizam conflitos históricos e sociais, objetivando analisar aquilo que Foucault (1969), citado por Maingueneau (1997, p.14), chama de formações discursivas: "Um conjunto de regras anônimas, históricas, sempre determinadas ao tempo e ao espaço que definiriam em uma época dada, e para uma área social, econômica, geográfica ou linguística das condições de exercício da função enunciativa”.

As formações discursivas permitem compreender, portanto, como o social se manifesta nas teias das práticas discursivas, apontando os efeitos das relações histórico-sociais na produção discursiva. O contexto histórico-social, ou o contexto da enunciação, constitui parte do sentido do discurso e não apenas um apêndice que pode ou não ser considerado. Enfim, pode-se dizer que, para a $\mathrm{AD}$, os sentidos são historicamente construídos.

Quanto à noção de sentido, Brandão (1993) ressalta que a significação discursiva é formada por meio da inter-relação entre dois espaços de produção de sentido - externo e interno - que se inter-relacionam em dois espaços enunciativos - de produção e de interpretação - com interposição de uma avaliação, sendo que ambas se articulam ao mesmo tempo uma sobre a outra.

$\mathrm{A} \mathrm{AD}$, ao se propor a não reduzir o discurso a análises estritamente linguísticas, mas abordá-lo também numa perspectiva sócio-histórica, não poderia constituir-se enquanto disciplina no interior de fronteiras rígidas, que não levassem em conta a interdisciplinaridade, seja com determinadas áreas das ciências humanas, como a História, a Sociologia, a Psicanálise, seja com certas tendências desenvolvidas no interior da própria Linguística, como a Semântica da Enunciação e a Pragmática. 
Sendo assim, o que se tem são vias, diferentes possibilidades de compreensão de um problema posto diferentemente por cada autor. Isso significa que não há uma teoria mais aceita, mas sim caminhos teóricos que respondem e corespondem em parte às necessidades de reflexão que se apresentam (MAINGUENEAU, 1997, p. 20-21).

Considerando, portanto, o caráter essencialmente interdisciplinar da AD e as considerações acerca do sentido e do papel das formações discursivas na produção desse sentido, elegeu-se, neste trabalho, como categoria de análise dos processos que compõem o corpus da pesquisa as unidades lexicais que delineiam a imagem do negro nas ações de liberdade. Essas análises objetivam, portanto, compreender como a imagem representada por meio do léxico trabalha enquanto estratégia argumentativa que procura sustentar o pedido de alforria desses escravos em uma sociedade na qual, em muitos dos casos, não havia lei que justificasse tal liberdade, ou seja, o trabalho pretende responder à seguinte pergunta: quem eram, nesses processos, os negros merecedores da alforria?

Ao abordar a questão da imagem, a AD volta suas preocupações, na maioria das vezes, para o estudo da imagem do locutor no discurso (noção de ethos discursivo). A utilização do termo "imagem”, neste trabalho, vai além dessa noção. Ao adotar o termo "imagem" e propor analisar a construção da imagem, o presente estudo está preocupado com a forma como um determinado sujeito social - no caso, o negro solicitante da alforria - é representado em práticas discursivas, nas quais ele próprio não tinha voz ativa, já que só podia falar por meio de seu curador; ou seja, pretende compreender como diferentes sujeitos sociais (senhores, curadores, testemunhas) representam o escravo, infligindo-lhe uma imagem por meio das escolhas lexicais operadas para construírem seus dizeres.

Para tanto, procurando-se respeitar a abordagem metodológica da AD, considera-se os textos enquanto superfície de manifestação das relações sociais vigentes na época em que eles foram produzidos. O trabalho se desenvolverá, portanto, na relação entre as propriedades internas do discurso e o exterior linguístico "procurando apreender como, no linguístico, as condições sócio-históricas de produção" se manifestam. (BRANDÃO, 1993, p. 83).

Considerando que a prática discursiva está intimamente ligada a outras 
séries de seu ambiente sócio-histórico, objetiva-se observar como esses elementos, que podem à primeira vista parecer muito distantes, se inter-relacionam na construção do dizer.

Dentro dessa perspectiva, considera-se que as unidades lexicais não possuem um sentido único, que lhes seja próprio, mas que elas assumem seu sentido na relação com as outras palavras com as quais se relacionam e em relação às formações discursivas nas quais ocorrem.

Concorda-se, portanto, com Pêcheux (1975) com que, se uma palavra assume um sentido diferente de acordo com a formação discursiva em que é empregada, é porque ela não tem um sentido literal. Seu sentido é dado na relação que ela mantém com outras palavras da mesma formação discursiva.

Concorda-se ainda com Foucault (1997), para quem é o enunciado que constitui o objeto e não o contrário.

Em uma palavra, quer-se, na verdade, renunciar às "coisas", "despresentificá-las"; conjurar sua rica, relevante e imediata plenitude, que costumamos considerar como a lei primitiva de um discurso que dela só se afastaria pelo erro, esquecimento, ilusão, ignorância ou inércia das crenças e das tradições ou, ainda, desejo, inconsciente talvez, de não ver e de não dizer; substituir o tesouro enigmático das "coisas" anteriores ao discurso pela formação regular dos objetos que só nele se delineiam; definir esses objetos sem referência ao fundo das coisas, mas relacionando-os ao conjunto de regras que permitem formá-los como objetos de um discurso e que constituem, assim, suas condições de aparecimento histórico; fazer uma história dos objetos discursivos que não os enterre na profundidade comum de um solo originário, mas que desenvolva o nexo das regularidades que regem sua dispersão (FOUCAULT, 1997, p. 54-55) (Grifos do original).

De acordo com essas afirmações, Foucault (1997, p. 51) ressalta que o discurso é o lugar por excelência de formação dos objetos. É através de 
práticas discursivas localizadas no interior de formações discursivas que os objetos são modificados, delineados e construídos. Essas formações discursivas é que determinam as condições para que o objeto apareça e para que se relacione com outros objetos, afinal, como afirma o autor "não se pode falar de qualquer coisa em qualquer época”. O objeto, portanto, não preexiste a si mesmo, mas existe apenas sob condições de um conjunto complexo de relações estabelecidas "entre instituições, processos econômicos e sociais, formas de comportamentos, sistemas de normas, técnicas, tipos de classificação, modos de caracterização". São essas relações que determinam o objeto, o que significa que ele não pré-existe a elas, mas se constrói/delimita no interior das tramas que as põem em relação.

\section{A alforria no Brasil: lei positiva, lei costumeira e as ações de li- berdade no século XIX}

A prática da alforria é tão antiga quanto à da própria escravidão. Ambas foram toleradas e legitimadas por diferentes povos, desde a Antiguidade. Segundo Ribeiro (1996), a palavra "alforria" é originária do árabe Al-burruâ, que "significa liberdade do cativeiro concedida pelo senhor ao escravo". "Manumissão" provém do latim manumissio ("libertar das mãos"), que compreende o ato de deixar forro um escravo ou de lhe dar carta de alforria. Dessa forma, "alforria" e "manumissão" se referem à condição jurídica alcançada pelo escravo que comprou e/ou recebeu a sua liberdade.

No Brasil, tanto o ato de escravizar os africanos e seus descendentes quanto o de alforriá-los basearam-se nos costumes incorporados na legislação portuguesa do Direito Romano, donde "o princípio regulador é que - partussequiturventrem [...] por forma que - ofilho da escrava nasce escravo-; pouco importando que o pai seja livre ou escravo" (MALHEIRO, 1976, p. 56).

Cunha (1984), em seu texto "Sobre os silêncios da lei: lei costumeira e positivas nas alforrias de escravos, no Brasil do século XIX", analisa o papel do Estado na mediação entre escravos e seus senhores referente ao processo de concessão da alforria durante o período de vigência da escravidão em nosso país. Segundo ela, ao contrário do que afirmaram alguns historiadores da época, baseados nos 
relatos de viajantes europeus, que o Estado garantia o direito à liberdade ao escravo que pagasse o valor da sua alforria, na verdade, isso se dava de maneira costumeira e à revelia do Estado, não porque este fosse alheio ao ato de alforriar, mas porque essa prática estaria resguardada ao universo do direito de propriedade e, portanto, da vontade senhorial em dispor ou não de seu cativo. Por isso, o Estado remediava e evitava a criação de leis que interviessem nos direitos e garantias jurídicas daqueles que possuíam escravos.

Como bem salienta a mesma autora, o direito à liberdade passava, portanto, pelos caminhos da lei costumeira, e o fato de reconhecer o senhor como o único capaz de se pronunciar a respeito da alforria não feria o seu direito de propriedade e reforçava ainda mais a dependência do escravo em relação à vontade do seu senhor.

O direito à alforria não existia em lei até 1871, ou seja, até a chamada Lei do Ventre Livre, que, além de declarar livres os filhos de escravos nascidos a partir daquela data, garantia outros direitos aos cativos, como, por exemplo, o de acumular pecúlios provenientes de doações, legados e heranças e, por consentimento do senhor, do seu trabalho e economias, resguardando o direito de obter meios para indenização do valor da sua alforria. Esse valor deveria ser fixado por um acordo estabelecido entre as partes interessadas ou, caso isso não ocorresse, seria estipulado arbitrariamente por meio de uma avaliação que levasse em conta, dentre outras coisas, o estado físico e a função exercida pelo escravo, como consta nos processos de ações de liberdade movidos contra os proprietários que negavam libertar os escravos que se encontravam nessa situação.

Contudo, antes da lei de 1871, existiam algumas circunstâncias excepcionais em que o Estado intervinha concedendo alforrias, por exemplo, àqueles que delatavam o contrabando de diamantes e, mais tarde, de madeiras. Com isso, os escravos que denunciavam o contrabando, mesmo testemunhando contra seus senhores, seriam alforriados. O mesmo ocorria com os que achassem diamantes pesando acima de 20 quilates.

Afora situações excepcionais, competia exclusivamente ao senhor conceder ou negar alforria a seu escravo. Na verdade, a lei costumeira, cuja existência ninguém podia duvidar, realmente vigia a prática da alforria. 
Diante dessa situação, o silêncio é o que mais chama a atenção, pois não havia nenhuma regulamentação antes de 1871 de uma prática tão largamente difundida. Se a lei escrita não se pronunciava a favor do direito à alforria paga, a lei costumeira, entretanto, seguia caminhos próprios.

Uma das mais importantes fontes para análise de disputas judiciais envolvendo senhores e escravos no Brasil é a ação de liberdade. O trabalho mais conhecido sobre esse processo judicial é "Liberata: a lei da ambiguidade - as ações de liberdade da Corte de Apelação do Rio de Janeiro no século XIX", escrito pela historiadora Keila Grinberg (1994). Nele, a autora analisa minuciosamente a ação de liberdade impetrada, em 1813, por Liberata, escrava de José Vieira Rebello que, através do seu curador, inicia uma longa disputa judicial junto ao juiz municipal do Desterro até alcançar sua tão almejada liberdade no final do século XIX. O processo de ação de liberdade, segundo Grinberg (1994), dava-se da seguinte forma: por meio de um requerimento, o juiz nomeava um curador para cuidar dos interesses do escravo, já que o negro não podia fazer a defesa de si mesmo; o curador, por sua vez, enviava um requerimento (libelo cível) expondo as razões por estar requerendo a liberdade; a partir dá, o advogado ou procurador do réu enviava outro libelo, apresentado sua defesa; o juiz, assim que recebesse a defesa, determinava a conclusão da ação, ou seja, apresentava o relatório do processo e divulgava o veredito; podia, ainda, o curador contestar a sentença do juiz, a fim de que este proferisse ou não nova sentença; era permitido, em certos casos, recorrer a $1^{\underline{a}}, 2^{\underline{\underline{a}}}$ e $3^{\underline{\underline{a}}}$ instâncias.

O escravo que não conseguisse um curador não podia dar prosseguimento à ação. A questão fundamental destacada por Chalhoub (1990) no que diz respeito às ações de liberdade é a intervenção do Estado no universo privado das relações estabelecidas entre senhores e escravos, uma vez que, legalmente, estes seriam propriedades daqueles e, portanto, somente o senhor deteria poder de decisão de libertar ou não o seu cativo. Além disso, segundo Chalhoub (1990, p. 100) "a concentração do poder de alforriar exclusivamente nas mãos dos senhores fazia parte de uma ampla estratégia de produção de dependentes, de transformação de ex-escravos em negros libertos ainda fiéis e submissos a seus antigos senhores".

Entretanto, se, de um modo geral, as leis resguardavam o poder dos se- 
nhores proprietários de escravos, por outro lado, apresentavam brechas, que permitiam aos escravos transitarem pelos caminhos jurídicos, em direção à tão sonhada liberdade. Com a intervenção do Estado, "os escravos passavam a ter meios institucionais de obter alforria à revelia do poder senhorial. Que isso comprometia a política de domínio na escravidão parece óbvio" (CHALHOUB, 2003, p. 186).

Segundo Slenes (1985), no Brasil, os escravos começam a recorrer à justiça, com mais frequência, a partir do século XIX, isso devido ao fato de que,

Com o crescimento do Estado no século XIX, o sistema judiciário se tornava cada vez mais presente, ao nível local, como regulador de propriedade e mediador entre pessoas; como resultado, outros fatores permanecendo iguais, o escravo ia aparecendo no cartório com mais e mais frequência (SLENES, 1985, p. 172).

Numerosos são os argumentos utilizados pelos curadores para justificar a obtenção da liberdade dos escravos: o direito à carta de alforria; a alegação de que o escravo (ou sua mãe, avó, bisavó) já havia sido libertado; a tentativa de compra da alforria; as acusações de violência e a alegação de o escravo ter chegado ao Brasil após o término do tráfico negreiro.

Considerando o fundamento histórico-social que envolvia as ações de liberdade, pode-se contextualizar o enquadramento dos sujeitos em uma sociedade dividida em senhores e escravos, na qual ambos desempenhavam diferentes papéis e assumiam interesses distintos. Nesse sentido, os sujeitos devem ser concebidos historicamente, levando-se em conta os valores que criavam e reproduziam a partir dos lugares que ocupavam na estrutura social e, especialmente, das diferentes relações que estabeleciam entre si no processo de conquista/concessão da alforria (CAMPOS; SILVA; OLIVEIRA, 2009, p. 168).

Não havendo nenhuma regulamentação legal da libertação do escravo até a Lei de 1871, esta se dava mediante diferentes acordos estabelecidos entre senhores e escravos. Um cativo poderia reclamar na justiça o direito a sua alforria quando, por exemplo, possuísse a quantia referente ao seu valor de mercado. Contudo, caberia unicamente ao seu senhor o direito de outorgá-la ou não. 
É interessante salientar, como destaca Cunha (1984), o fato de, antes de 1871, a lei se silenciar a respeito desses processos, pois o que pesava nessa relação era o direito de propriedade, garantido na Constituição de 1824. Como bem salienta a autora, o direito à liberdade passava, portanto, pelos caminhos da lei costumeira, e o fato de se reconhecer o senhor como o único capaz de se pronunciar a respeito da alforria não feria o seu direito de propriedade e reforçava ainda mais a dependência do escravo em relação à vontade do seu senhor.

\section{Análise do corpus}

Nesta seção, com fundamento no quadro teórico-metodológico e nas condições de produção dos textos componentes da pesquisa, serão analisados dois processos de ação e manutenção de liberdade, movidos na Comarca do Rio das Mortes, a saber: o de Anna Crioula, datado de 1838, e o de Ritta Guilhermina de Jesus, datado de 1863. Nesses processos, foram selecionados trechos nos quais diferentes sujeitos sociais (curador, testemunhas e senhores) constroem a imagem do escravo merecedor da alforria.

É interessante se destacar uma vez mais que, apesar de serem os interessados diretos nos processos, os escravos não tinham voz no seu desenrolar, sendo representados pelos seus curadores. Observa-se, portanto, como a instituição jurídica e as formações discursivas punham em prática os princípios de exclusão, conforme propostos em Foucault (1996). Segundo esse autor, há três princípios de exclusão externos controlando a produção discursiva. O primeiro seria o princípio da interdição, o qual estaria ligado à relação do discurso com o poder. Segundo Foucault (op. cit.), esse princípio é aquele que se relaciona ao fato de que não se tem o direito de falar tudo, não sendo permitindo a qualquer um falar qualquer coisa. Esse princípio estaria ligado, neste trabalho, à questão do acesso ao discurso jurídico, determinando quem pode falar o que, ou seja, a quem é dado o direito de voz. O segundo princípio de exclusão seria a rejeição, que em Foucault está ligado à relação razão e loucura. O discurso do louco seria aquele impedido de circular como o dos outros, determinando que sua palavra não tem importância. Podemos associar esse princípio à rejeição da voz dos escravos nas ações de liberdade, à medida 
que eles não detêm o discernimento para pronunciar palavras racionais. Finalmente, o terceiro princípio de exclusão discutido por Foucault seria o da oposição verdadeiro/falso. O discurso verdadeiro é aquele pronunciado por quem tem o direito de falar, relacionando-se ao modo como "o saber é aplicado em uma sociedade, como é valorizado, distribuído, repartido e de certo modo atribuído" (Foucault, 1996, p. 17). Essa vontade de verdade estaria, portanto, diretamente ligada aos outros princípios de exclusão, exercendo sobre todos os discursos uma espécie de coerção. É em busca desse verdadeiro que se permite a exclusão de determinadas vozes no discurso jurídico, comprometidas com o que a sociedade reconhece como falso: falsos valores, razões falsas.

Com base nos itens lexicais selecionados nos exemplos abaixo, veja-se, pois, como se constrói a imagem do escravo candidato à alforria nos processos citados.

Anna Crioula (1838): Nesse processo de ação de liberdade a escrava Anna Crioula solicita na justiça o reconhecimento da vontade se seu senhor, já falecido, em tornar ela e seus filhos livres. O processo se desenrola por meio da oitiva de testemunhas e do relato do curador, já que o proprietário da referida escrava morre antes de fazer seu testamento (ab intestado).

1 - "Ele [o senhor], em gratidão ereconhecimento pela amizade e mesmo pelo amor de criação que thes consagrava; constante e publicamente dizia que a primeira suplicante e todos os seos filhos e descendentes, por sua morte ficariam libertos, não passando a outro captiveiro e que além disso lhes deixaria arranjos de vida. Nesta esperança, a conduta dos suplicantes jamais fez com que desmerecessem a contemplação do dito, seo senhor e bem feitor, que até o seo falecimento não mudou de vontade". (Curador)

2 - "Vivendo sempre o ab intestado no estado de solteiro em que não teve filhos, $e$ nem parentes em qualquer grau neste Império, amava com extremo aos Embargantes tanto pela amizade contrabida com a primeira, como pelo amor de criação que consagrava a seos filhos decendentes". (Testemunha) 


\section{3 -"Porque os Embargantes nunca dismerecerão a contemplação do Ab in-} testado, e antes prestando-lhe bons serviços; sempre se portarão com elle com muita umildade e respeito, circunstancias estas que fizerão ratificar o seo amor epredilecção tanto assim." (Testemunha)

4 - "...] que sabe por certo que a embargante Anna alterou algumas razoins com Manoel Pereira, o qual para vingar, pretendeu comprá-la e falando nisso ao Ab intestado, elle the respondeu asperamente, que a mesma Embargante, hera tambôa com elle e mesmo heram todos os seos filbos [...]." (Testemunha)

5 -"...] que os embargantes prestavam bons serviços a seo senhor, portando-se para com este com muita bumildade erespeito [...'" (Testemunha)

Nesses trechos, confirmando o que propõem Cunha (1984) e Chalhoub (1990), percebe-se que o direito à alforria fica totalmente sujeito à vontade do senhor. Isso pode ser percebido nas falas das testemunhas e do próprio curador dos escravos que, considerando o fato de o proprietário de Anna Crioula (e seus descendentes) ter morrido sem fazer o testamento, procuram provar em seus relatos a veracidade de seu desejo em dar-lhes como forros após sua morte, como evidenciam os seguintes trechos: "Ele [o senhor] [...] constante e publicamente dizia que a primeira suplicante e todos os seos filhos e descendentes, por sua morte ficariam libertos"; "...J amava com extremo aos Embargantes tanto pela amizade contrabida com a primeira, como pelo amor de criação que consagrava a seos fiIhos decendentes; "...] os Embargantes nunca dismerecerão a contemplação do Ab intestado, e antes prestando-lhe bons serviços, sempre se portarão com elle com muita umildade e respeito, circunstancias estas que fizerão ratificar o seo amor e predilecção tanto assim."; "...] Ab intestado, elle lhe respondeu asperamente, que a mesma Embargante, hera tambôa com elle e mesmo heram todos os seos filhos"; "...] que os embargantes prestavam bons serviços a seo senhor, portando-se para com este com muita humildade e respeito". Nesses excertos, com o intuito de deixar clara a vontade do senhor em ver libertos seus escravos após a morte, já que, historicamente, a alforria estava sujeita a essa vontade, a fala do curador e das teste- 
munhas se inscreve perceptivelmente em uma formação discursiva escravocrata na medida em que as unidades lexicais presentes em seus dizeres se associam única e exclusivamente à vontade do senhor, seja ficar claro que essa vontade era "constante e publicamente" expressa pelo ab intestado, seja ao se aliar o direito à alforria ao amor que o senhor nutria pelos cativos.

Mas em relação à imagem do escravo, no caso da escrava e seus filhos, como ela é construída nesses trechos? As unidades e expressões lexicais destacadas permitem a percepção de que se recria a imagem do escravo fiel, amigo, de boa conduta, prestador de bons serviços, humilde, bom e respeitador, merecedor do amor e gratidão de seu senhor, como se pode perceber nos seguintes trechos: gratidão e reconhecimento pela amizade e mesmo pelo amor de criação; a conduta dos suplicantes jamais fez com que desmerecessem a contemplação do dito; amizade contrahida com a primeira, como pelo amor de criação que consagrava a seos filhos decendentes; os Embargantes nunca dismerecerão a contemplação do Ab intestado, e antes prestando-lhe bons serviços; sempre se portarão com elle com muita umildade e respeito, circunstancias estas que fizerão ratificar o seo amor e predilecção tanto assim; hera tambôa com elle e mesmo heram todos os seos filhos; prestavam bons serviços a seo senhor, portando-se para com este com muita humildade e respeito.

Segundo a historiadora Kátia Mattoso (1990, p. 170), a fidelidade, a obediência e a humildade eram as três qualidades que poderiam levar um escravo a alcançar legalmente a sua liberdade. Agindo dessa forma, os escravos domésticos eram os mais privilegiados na concessão da alforria, especialmente, os crioulos ou mestiços que gozavam de certa afeição senhorial. Para Campos, Silva e Oliveira (2009, p.98) alguns argumentos alegados pelos testadores são bem reveladores quanto a isso: "por ser cria de minha casa", "pelo amor com que lhe criei", "pelo amor com que sempre me tratou", "pelos bons serviços que me tem prestado", "pelo amor com que me tratou em minhas enfermidades".

Considerando-se a formação discursiva vigente na época - escravocrata, na qual se considerava o escravo enquanto um bem, uma propriedade -, à primeira vista, pode-se considerar que a construção da imagem do negro, embasada em 
preceitos sentimentais e humanos pode ir de encontro a essa FD. Entretanto, com base naquilo que os estudos históricos revelam sobre o período em questão, entende-se que a imagem do negro fiel e, por isso, merecedor da gratidão de seu senhor, na verdade, procurava reforçar os laços éticos e morais entre senhores e escravos, alimentando nestes a necessidade de se portarem de modo a merecerem, um dia, a concessão da alforria, e naqueles, tanto a manutenção do direito à propriedade quanto a imagem de que eram capazes de reconhecer os bons serviços prestados. Assim, reforçava-se não só o direito à propriedade, como também a dependência do escravo à vontade do senhor, ao qual deveria ser fiel, amigo, respeitador se almejasse receber sua carta de alforria.

Nesse sentido, comprovam-se as afirmações de Pêcheux (1975) e Foucault (1997) de que o sentido das palavras (os objetos) não preexiste a si mesmo, mas deve ser analisado no interior das formações discursivas em que emergem, na relação com as outras palavras com as quais coexistem no interior dessas FDs. Assim, palavras como "amor", "gratidão", "humildade", "bondade", "respeito" e "predileção"- como identificamos nos trechos citados $\neg-$, que, inicialmente podem ser associadas a valores/sentimentos positivos, assumem novo matiz semântico ao se inscreverem nessa formação discursiva escravocrata, na medida em que procuram alimentar a imagem do escravo fiel e do senhor capaz de reconhecer essa fidelidade e, por isso, conceder a alforria.

Ritta Guilhermina de Jesus (1863): Nessa ação de manutenção de liberdade, a escrava Ritta Guilhermina de Jesus contesta a petição apresentada por José Joaquim da Cruz, filho e herdeiro de Anna Francisca de Jesus (senhora falecida da escrava), na qual o autor alegava ser falsa a carta de alforria que a negra afirmava ter recebido de sua senhora. Como o objetivo do trabalho ora proposto é a investigação acerca da imagem do negro, selecionou-se para análise um trecho da carta de alforria apresentada pela escrava (concedida a ela pela senhora antes de falecer) e o depoimento de uma testemunha sobre a veracidade do desejo da senhora em libertar seus escravos.

6 - "[...] Digo eu abaixo assignada Anna Francisca de Jesus, viñva que fiquei por 
falecimento de meu marido Joaquim Rodrigues dos Santos, que entre os meus bens que sou Senhora e possuidora com livre e geral administração há bem assim buma crioula por nome Ritta Guilhermina de Jesus, cuja escrava pelo amor que lhe tenho e aosbons serviços que essa me tem prestado be de minha ultima vontade sem constrangimento de pessoa alguma que depois do meu falecimento, que a dita Escrava fique ella gosando de plena liberdade como pessoa que livre fosse [...]." (carta de alforria apresentada pela escrava para manutenção de sua liberdade).

7 - "É pois, de meu conbecimento que a doadora pelo amor que naturalmente tinh a a estes escravos por havelos criado e mesmo por que sempre lhe renderão obdiencia, accatamento, e respeito vivendo em sua companbia sem lhe causar disgastes, socorrendo por muitas vezes as necessidades da casa a [...] de suas economias ganhas nos domingos e dias santos (como é publico) e por ter um coração bom querendo que por seu falecimento gozassem da liberdade aquelles seus escravos [...]." (testemunha)

Também nesses trechos, como nos anteriores, percebe-se que a imagem do negro se constrói no limiar entre o fato de ser propriedade, a fidelidade e bons serviços prestados a seu senhor e a caridade desse senhor que, em reconhecimento a seus serviços e por possuir um bom coração, decide conceder-lhe a alforria. Isso pode novamente ser constatado nas escolhas lexicais operadas nos trechos em questão, atentando-se, nesses exemplos, para a particularidade de o reconhecimento do negro enquanto propriedade estar expresso claramente nas expressões: "entre os meusbens que sou Senbora e possuidora com livre e geral administração há bem assim huma crioula por nome Ritta Guilhermina de Jesus"; "que a doadora pelo amor que naturalmente tinha a estes escravos [...] querendo que por seu falecimento gozassem da liberdade aquelles seus escravos [...?'.

Desse modo, se no processo anterior a imagem do negro como propriedade vinha, de certa forma, disfarçada no reconhecimento de sua imagem enquanto pessoa, ser humano capaz de oferecer e merecer sentimentos, e reforçada pelo reconhecimento do senhor enquanto único capaz de lhe conceder a liberdade; nes- 
te último, essa imagem vem claramente expressa pelas palavras da senhora na carta de alforria e mesmo da testemunha ouvida no processo.

Comprovando a análise anterior, de que discursos aparentemente antagônicos (um discurso escravocrata em que o negro era uma propriedade e um discurso que o via, aparentemente, como ser humano) trabalham na reafirmação da FD escravocrata, nesses últimos exemplos, essa relação fica mais explícita. Neles, em um primeiro momento o negro é apresentado como propriedade para, em um segundo momento, justificar-se sua alforria pelo amor que foi capaz de despertar em sua senhora pelos bons serviços prestados, pela obediência, acatamento, respeito e pela companhia fiel que lhe oferecera.

É importante enfatizar, novamente, que as justificativas mais comuns declaradas pelos senhores de ambos os sexos para essas dádivas referem-se aos "bons serviços prestados", "fidelidade" e "pelo amor de Deus". Argumentando sobre isso, Eduardo Paiva (1995, p.107) observa que, muitas vezes, para o cativo,

tornar-se ou fazer-se passar por passivo, amável e fiel resultou em muitas cartas de alforrias justificadas nos "bons serviços prestados", na "lealdade e sujeição", expressões recorrentes nos testamentos e empregadas mesmo quando tratava-se de manumissões pagas. Nesse momento as estratégias engendradas no dia a dia obtinham sucesso.

Observa-se, mais uma vez, que o discurso construído em torno da imagem do negro merecedor da alforria alimenta as relações entre senhores e escravos de modo a manter os princípios éticos em suas relações, principalmente, em torno da imagem do negro fiel e do senhor caridoso, não ferindo o direito à propriedade.

Essa representação do negro fiel e do negro como propriedade era tão forte na memória discursiva do século XIX que pode ser facilmente encontrada na literatura da época. Segundo Brookshaw (1983), a presença do negro na literatura anterior à abolição do tráfico de escravos (1850) é praticamente inexistente, comprovando que "o escritor brasileiro não considerava o escravo de modo nenhum um ser humano" (p. 26). Para o autor, se o negro começou a aparecer na literatura 
indianista, como no romance Til (1872), de José de Alencar, foi para contrastar com a figura do índio. Enquanto o índio era corajoso e independente, a figura do negro na literatura era representada pela "índole escrava, humilde e resignada" (p. 27). Mesmo após 1850, com a abolição do tráfico de escravos, a imagem do escravo sofrido, fiel e nobre ainda habitava, segundo Brookshaw (op. cit.), a produção literária brasileira, sintetizando a "natureza suave, passiva e fiel do escravo" (p. 29).

Percebe-se, pois, que as relações sociais entre senhores e escravos eram construídas e realimentadas o tempo todo pelo discurso em torno da escravidão. Desse modo, se por um lado as formações discursivas vigentes em uma dada época são formadas com base nas relações sociais e de poder dessa época, por outro lado, elas procuram trabalhar de forma a manter essas relações por meio dos discursos que se produzem em seu interior e das coerções presentes no interior das FDs que procuram limitar o que pode ser dito em relação àquilo que é considerado verdadeiro naquela época e quem tem permissão para dizer o que pode ser dito. Nesses termos, vimos, nos processos, que a construção da imagem do escravo se dá no limiar entre o fato de ser propriedade e a capacidade de despertar sentimentos e senti-los como um ser humano. Esses discursos que, inicialmente, podem parecer antagônicos, ao constituírem, interdiscursivamente, a formação discursiva escravocrata procuram, como vimos, alimentar não só as relações sociais vigentes, mas também a necessidade de fidelidade do escravo e a bondade do senhor que pode vir a reconhecer os bons serviços prestados com a concessão da alforria. No que tange ao poder da FD em determinar quem tem o direito à palavra numa dada época, fica evidente nos processos que ao escravo não era facultada a autorização de sustentar o dizer, já que, enquanto "propriedade", não tinha reconhecimento para falar.

Assim, percebe-se que a rede semântica de uma determinada prática discursiva coincide com as relações desse discurso com seu Outro. Portanto,

mesmo quando a justificativa da libertação do escravo baseia-se em valores que reconheciam neste um ser humano dotado de e capaz de despertar sentimentos, tal discurso vinha atravessado pelo reconhecimento do escravo enquanto um bem, alimentando 
a relação de propriedade entre ele e seu senhor. (CAMPOS; SILVA; OLIVEIRA., 2009, p. 168)

Barros (1997), contudo, postula que os discursos são, por definição, dialógicos, podendo, no entanto, construir efeitos de sentido de polifonia ou de monofonia. Trata-se, no primeiro caso, de textos em que o dialogismo se deixa ver, o que não ocorre nos textos monofônicos, que escondem as vozes que os constituem.

Por outro lado, Maingueneau (2007) afirma que a unicidade dos discursos é apenas aparente e que os sentidos se constroem, na verdade, nos limites das FDs, o que permite ao autor afirmar a primazia do interdiscurso sobre o intradiscurso. Nessa vertente, De Nardi (2003) destaca que o retorno à memória, ao préconstruído não pode ser visto como mera reprodução, mas antes como ressignificação do já dito que "apontará tanto para o sentido já-posto, quanto para novas possibilidades de produção de sentidos" (p. 77).

É, portanto, na noção de primazia do interdiscurso, ou seja, na relação da formação discursiva com o seu exterior, permitindo o vislumbre de novas possibilidades de sentido, que este trabalho se filia para propor um sentido novo, além dos já apresentados, para o discurso jurídico em torno dos processos de ação de liberdade.

Assim, se, por um lado, nesses processos o negro era representado enquanto agente passivo na luta pela sua alforria, não tendo direito a voz e ficando sua liberdade sujeita à vontade única de seu senhor, por outro, pode-se conferirlhe uma imagem ativa na luta pela liberdade, já que dependia única e exclusivamente dele a procura da justiça para solicitar o reconhecimento de seu direito à liberdade.

Nesse sentido, ainda que em seu interior a formação discursiva ligada à estrutura de poder vigente na época procurasse apagar, nas práticas discursivas, o conflito de interesses envolvido em um processo de ação de liberdade (tanto pela reafirmação do direito de propriedade quanto pela construção da imagem do negro de forma a alimentar as relações éticas dele em relação a seu senhor), a própria gênese da ação de liberdade mostra o papel ativo do negro na luta pelo seu direito 
à alforria, ainda que, para isso, tivesse que se sujeitar às restrições impostas pela formação discursiva.

Dessa forma, ao se pôr em evidência a relação da formação discursiva com seu exterior, pretende-se, conforme Orlandi (2001), retirar o negro da posição de passividade e transformá-lo em agente ativo do processo histórico de luta pela liberdade e resistência à escravidão, inaugurando "uma discursividade centrada no problema da afirmação do negro enquanto sujeito, e não mais apenas no efeito de saber" (ORLANDI, 2001, p. 67).

É no âmbito do interdiscurso, portanto, que os processos de ação de liberdade devem ser compreendidos para que os sentidos aparentes, manifestos na superfície textual, deem lugar a novas possibilidades de sentido por meio da ressignificação do já-dito.

\section{Considerações finais}

Com o objetivo de analisar a construção da imagem do negro em processos de ação e manutenção de liberdade do século XIX, impetrados na Comarca do Rio das Mortes, este trabalho procurou se inscrever em um quadro interdisciplinar que comungasse os pressupostos teórico-metodológicos da Análise do Discurso e as investigações históricas do período em que esses processos tramitaram.

Para tanto, em um primeiro momento, procurou-se delinear o quadro teórico-metodológico de análise, abordando-se alguns preceitos fundamentais da análise do discurso - como a relação entre o discurso e o histórico-social, a noção de sentido, o papel das formações discursivas e do interdiscurso na produção desse sentido. Procurou-se também definir a categoria de análise e delimitar a própria noção de construção de imagem.

Posteriormente, com o objetivo de fornecer o conhecimento histórico-social necessário ao enquadramento dos textos às suas condições de produção, passou-se ao estudo histórico das relações sociais vigentes na época em que os processos ocorreram, bem como à compreensão do que vinha a ser uma ação de liberdade e como se dava sua tramitação legal.

Em um terceiro momento, com fundamento nas discussões teóricas apre- 
sentadas, procurou-se investigar como se dava a construção da imagem do negro nos textos das ações de liberdade, por meio da análise das unidades e expressões lexicais presentes nesses textos.

Nessa etapa, observou-se que a imagem do negro era construída com o objetivo não só de manutenção do direito de propriedade de seu senhor como também das relações éticas e morais entre esses sujeitos sociais, atendendo-se à formação discursiva ligada à estrutura de poder vigente na época. Essa conclusão pôde ser tirada a partir da identificação de palavras e expressões que ressaltavam a posse do senhor sobre seus escravos, ficando condicionada a alforria destes, única e exclusivamente, ao desejo daquele. Foi constatado também nos itens lexicais analisados que, não havendo amparo legal para a concessão da liberdade ao escravo, esta se justificava pelo reconhecimento dos bons serviços prestados pelo negro e pela bondade e gratidão do senhor. Argumentou-se, ainda, que se, inicialmente, pode parecer contraditória a presença dessa imagem do negro em uma FD escravocrata, assumindo-se a tese de que o sentido das palavras não preexiste a si mesmo, mas se constrói no interior da FD à qual essas palavras se filiam, essa contradição é desfeita. Nesse sentido, foi possível observar que, ao trazer para o seu interior o discurso que reconhecia aparentemente no negro um ser capaz de despertar sentimentos e também de sentir, a FD escravocrata buscava, na verdade, alimentar as relações éticas entre senhor e escravo.

Entretanto, com base no primado do interdiscurso sobre o intradiscurso, viu-se que, na verdade, os limites que separam a formação discursiva de seu exterior são muito tênues não sendo capazes de impedir que sentidos antagônicos possam emergir em seu interior. Nesses termos, propôs-se uma nova possibilidade de análise para os sentidos expressos no interior da formação discursiva, inaugurando-se uma nova discursividade em que o negro, de passivo, possa se tornar sujeito ativo no processo de luta pela liberdade.

Finalizando este trabalho, faz-se importante destacar como os sentidos que irrompem do já-dito são importantes na própria compreensão da identidade racial brasileira.

Dessa forma, a construção da imagem do negro em nosso país está visceralmente ligada ao seu passado de mais de trezentos e cinquenta anos sob a vi- 
gência legal do sistema escravista, o último das Américas a se desvincular da exploração do trabalho de milhares de africanos arrancados de seu continente pelo tráfico atlântico e dos seus descendentes que, aqui, nasciam. A identificação de estereótipos negativos do negro, na sociedade brasileira, está intimamente ligada à forma como abordamos o seu passado na nossa história vinculado a imagens dos maus-tratos do tráfico, dos negros sendo açoitados e trabalhando nos engenhos de açúcar, na mineração e nas fazendas de café.

Embora sendo importante na construção e, sobretudo, na formação da identidade brasileira, o negro teve e continua tendo o seu passado ligado à escravidão. Seria impossível fazer o que determinou Rui Barbosa, Ministro da Fazenda, no Governo de Deodoro da Fonseca, em 15/12/1890: queimar todos os documentos referentes à escravidão negra no Brasil existente no ministério, como se isso fosse capaz de apagar essa parte da história do nosso país (MOURA, 2004, p. 65).

Assim, se não se podem apagar as marcas que a escravidão impeliu sobre a imagem do negro no país, cabe investigar como as formações discursivas escravocratas se relacionam com seu exterior, propondo ressignificações à memória discursiva sobre o negro no Brasil, especialmente aquelas ligadas aos registros das lutas ativas pela liberdade, como as que encontramos nas ações de liberdade.

\section{Referências}

Arquivo do IPHAN de São João del-Rei, cópia da Ação de Liberdade de Anna Crioula (1838), caixa n. 001.

Arquivo do IPHAN de São João del-Rei, cópia da Ação de Ritta Guilhermina de Jesus (1863), caixa n. 001.

BARROS, Diana Luz Pessoa de. Contribuições de Bakhtin às teorias do discurso. In: BRAIT, Beth (org.). Bakhtin, dialogismo e construção do sentido. Campinas: Ed. UNICAMP, 1997. p. 27-36.

BELLINI, Ligia. Por amor e por interesse: a relação senhor-escravo em cartas de alforria. In: REIS, João José (Org.). Escravidão e invenção da liberdade: estudos sobre o negro no Brasil. São Paulo: Brasiliense, 1988.

BRANDÃO, Helena H. Nagamine. Introdução à Análise do Discurso. Campinas: Ed. UNICAMP, 1993. 
BROOKSHAW, David. Literatura abolicionista: a criação do estereótipo. In: BROOKSHAW, David. Raça e Cor na Literatura Brasileira. Porto Alegre: Mercado Aberto, 1983.

CAMPOS, Carla Leila Oliveira; SILVA, Cristiano Lima da; OLIVEIRA, Sabrina Marcília. O papel argumentativo dos valores em ações de liberdade do século XIX na comarca do Rio das Mortes. Vertentes, n. 34, p. 158-169, jul./dez. 2009.

CHALHOUB, Sidney. Visões da liberdade: Uma história das últimas décadas da escravidão na corte. São Paulo: Companhia das Letras, 1990.

CHALHOUB, Sidney. Machado de Assis Historiador. São Paulo: Companhia das Letras, 2003.

CUNHA, Manuela Carneiro da. Sobre os silêncios da lei: lei costumeira e positiva nas alforrias de escravos no Brasil do século XIX. Revista Mexicana de Sociologia, ano XLVI, v. XLVI, n. 2, p. 45-59, abr./jun. 1984.

DE NARDI, Fabiele Stockmans. Entre a lembrança e o esquecimento: os trabalhos da memória na relação com língua e discurso. Organon,v. 17, n. 35, p. $65-$ 83, 2003.

FOUCAULT, Michel. L'Archéologie du Savoir. Paris: Gallimard, 1969.

FOUCAUlT, Michel. A Ordem do Discurso. São Paulo: Loyola, 1996.

FOUCAULT, Michel. As regularidades discursivas. In: FOUCAULT, Michel. A arqueologia do saber. Rio de Janeiro: Forense, 1997. p. 21-85.

GRAÇA FILHO, Afonso de Alencastro. A Princesa do Oeste e o Mito da Decadência de Minas Gerais: São João del-Rei (1830-1888). São Paulo: Annablume, 2002.

GRINBERG, Keila. Liberata - a lei da ambiguidade: as ações de liberdade da Corte de Apelação do Rio de Janeiro no século XIX. Rio de Janeiro: Relume Dumará, 1994.

MAINGUENEAU, Dominique. Gênese dos discursos. Curitiba: Criar, 2007. MAINGUENEAU, Dominique. Novas tendências em análise do discurso. Campinas: Pontes/Ed. da UNICAMP, 1997.

MALHEIRO, Perdigão. A Escravidão no Brasil: Ensaio Histórico, Jurídico, Social. 3. ed. Petrópolis: Vozes, 1976.

MATTOSO, Kátia M. de Queirós. Ser escravo no Brasil. 3. ed. São Paulo: 
Brasiliense, 1990.

MOURA, Clóvis. Dicionário da escravidão negra no Brasil. São Paulo: Editora da Universidade de São Paulo, 2004.

ORLANDI, EniPulcinelli. A boa nova da memória anunciada: o discurso fundador da afirmação do negro no Brasil. In: ORLANDI, Eni P. (Org.). Discurso Fundador: a formação do país e a construção da identidade nacional. Campinas: Pontes, 2001. p. 59-68.

PAIVA, Eduardo França. Escravos e libertos nas Minas Gerais do século XVIII: estratégias de resistência através dos testamentos. São Paulo: Annablume, 1995. PAIVA, Eduardo França. Pelo justo valor e pelo amor de Deus: as alforrias nas minas. In: Seminário sobre a Economia Mineira, 9, Diamantina, 2000. Anais. v. 1. Diamantina: CEDEPLAR/UFMG, 2000.

PÊCHEUX, Michel. Semântica e Discurso: uma crítica à afirmação do óbvio. Campinas: Unicamp, 1975.

POSSENTI, Sírio. Teoria do Discurso: um caso de múltiplas rupturas. In: MUSSALIM, Fernanda; BENTES, Anna Christina. (Orgs.). Introdução à Lingüística 3: fundamentos epistemológicos. São Paulo: Cortez, 2007. p. 353-392.

RIBEIRO, Núbia Braga. Cotidiano e liberdade: um estudo sobre os alforriados em Minas Gerais no século XVIII. 1998. 79 f. (Dissertação - Mestrado em História) Universidade de São Paulo, São Paulo, 1996.

SLENES, Robert W. Escravos, cartórios e desburocratização: o que Rui Barbosa não queimou será destruído agora? Produção e Transgressões: Revista Brasileira de História (ANPUH), v. 5, n. 10, p. 166-196, mar/ago 1985.

${ }^{i}$ Artigo resultante de projeto de pesquisa desenvolvido no Instituto de Ensino Superior Presidente Tancredo de Almeida Neves (IPTAN/São João del-Rei) sob fomento da FUNADESP e da FAPEMIG.

${ }^{i i}$ Bacharel em Direito pelo IPTAN. Bolsista de Iniciação Científica do programa PIBIC/ FAPEMIG.

iiiSegundo Graça Filho (2002), a vila de São João del-Rei foi instituída cabeça da Comarca do Rio das Mortes no Alvará de 6 de abril de 1714. Embora tenha sofrido inúmeras alterações em sua geografia administrativa desde a sua criação, inicialmente sua jurisdição 
estendia-se pelo centro-sul, a sudoeste da capitania, compreendendo os termos de Jacuí, Baependi, Campanha da Princesa, Barbacena, Queluz, Nossa Senhora de Oliveira, São José do Rio das Mortes e Tamanduá. Destarte, no início do século XIX, já se configurava como a mais extensa em área habitada e a mais populosa da então capitania de Minas Gerais. Com a transferência da Corte para o Brasil, em 1808, São João del-Rei configurou-se como sendo um importante eixo de escoamento da produção regional e de abastecimento interno para a Praça do Rio de Janeiro, permanecendo como importante centro administrativo e jurídico da Comarca do Rio das Mortes durante todo o século XIX.

${ }^{i v}$ Inspirada em Pêcheux, De Nardi (2003, p. 77) afirma que, em oposição ao intradiscurso, o interdiscurso "representa uma dimensão não-linear do dizer [...], sua verticalidade fazendo-nos ingressar no campo do pré-construído, do já dito para o qual o sujeito se volta ao identificar-se com a FD a partir da qual constituirá o seu discurso". O olhar volta-se, então, para a rede das FDs em que o discurso em questão se insere, sendo importante lembrar que esse retorno não é uma mera reprodução, mas antes a ressignificação do já-dito, que "apontará tanto para o sentido já-posto, quanto para novas possibilidades de produção de sentidos.” Já em relação ao intradiscurso, a mesma autora o define como o "efeito do interdiscurso sobre si mesmo". O intradiscurso é, pois, "o fio do discurso, a dimensão horizontal, linear do dizer que nos possibilita entender o que aquele que enuncia efetivamente diz em relação ao que disse antes e acabará por dizer depois. O intradiscurso refere-se ao funcionamento do discurso em relação a si mesmo." ${ }^{\mathrm{v} C o m o ~ t a m b e ́ m ~ f o r a ~ o b s e r v a d o ~ p o r ~ B e l l i n i ~(1988) ~ e ~ P a i v a ~(2000) . ~}$

Data de submissão: 10/01/2011

Data de aprovação: 25/06/2012 
